\title{
Estimates of Genetic Variability for Growth Parameters in Amaranth (Amaranthus L.) Species
}

\author{
Sheela N. Malaghan*, S. Revanappa, Mansur, D. Satish and P.S. Ajjappalavar
}

Department of Horticulture, College of Horticulture, Bagalkot, University of Horticultural

Sciences, Bagalkot - 587 103, India

*Corresponding author

\begin{abstract}
A B S T R A C T
Keywords

Amaranth, Genetic

variability,

Heritability,

Genetic advance and kharif

Article Info

Accepted:

10 June 2018

Available Online:

10 July 2018

Forty four genotypes of amaranth spp were evaluated during kharif and rabi seasons of 2015 - 16 at University of Horticultural Sciences, Bagalkot. Observations were recorded on plant height at 15 DAS $(\mathrm{cm})$, plant height at 30 DAS $(\mathrm{cm})$, stem diameter $(\mathrm{cm})$, leaf length $(\mathrm{cm})$, leaf breadth $(\mathrm{cm})$, petiole length $(\mathrm{cm})$, leaf to stem ratio, leaf dry matter content $(\%)$, stem dry matter content $(\%)$ and total dry matter content $(\%)$. The results revealed statistically significant differences among genotypes for all traits at both kharif and rabi seasons. High GCV and PCV were observed for plant height at 15 DAS (cm), plant height at 30 DAS $(\mathrm{cm})$, stem diameter $(\mathrm{cm})$, leaf length $(\mathrm{cm})$, leaf breadth $(\mathrm{cm})$, leaf to stem ratio and stem dry matter content (\%). High estimates of heritability coupled with high genetic advance were recorded for plant height at 30 DAS, plant height at 15 DAS, stem diameter $(\mathrm{cm})$, leaf length $(\mathrm{cm})$, leaf to stem ratio and stem dry matter content $(\%)$. The result of present investigation, indicating that additive gene effects were operating for these characters and selection pressure could be applied on them for plant growth and yield improvement.
\end{abstract}

\section{Introduction}

Amaranthus belongs to family Amaranthaceae and having a chromosome number $2 \mathrm{n}=34$, order Caryophyllales comprises about 800 species in 60 genera of herbaceous annual plant, rarely shrub. Amaranthus is the most delicious leafy vegetable of tropical, sub tropical and temperate regions of the world and it also grown an important grain crop of Himalayan region as reported by (Joshi and Rana, 1995). Amaranth leaves are a rich and inexpensive source of dietary fibre, protein, vitamins and a wide range of minerals
(Prakash and Pal 1991; Shukla et al., 2003). Unlike other leafy vegetables, amaranth does not require cold climate for good growth and can be cultivated during mild summers (Singh and Whitehead, 1996). Vegetable amaranth serves as an alternative source of nutrition for vegetarian people in developing countries where the bulk of the population has little access to protein rich food. Besides its immense nutritional importance, it can grow successfully under varied soil and agroclimatic conditions (Katiyar et al., 2000; Shukla and Singh, 2000). 
Being a cheap source of protein, emphasis is laid on its genetic improvement to enhance its potentiality for foliage yield through different contributing traits. Through collection and selection programmes, a number of strains have been introduced and acclimatized in various parts of the world, but evaluation studies of yield and its contributing quantitative and qualitative traits are scarce (Shukla and Singh, 2002). Improvement of foliage growth requires in depth knowledge of the magnitude of variation present in the available germplasm, interdependence of quantitative characters with yield, extent of environmental influence on these factors, heritability and genetic gain of genetic material. Therefore, to fill the lacuna, an experiment was carried out to study different selection parameters for important foliage growth contributing traits to chalk out an effective breeding plan. The present study was conducted to quantify the leaf growth attribute parameters in different strains on the one hand and genetic variability among the strains on the other. Based on the biometrical studies a selection programme for the improvement of foliage growth and yield through its contributing traits has been chalked out.

\section{Materials and Methods}

The experimental material consisted of forty four indigenously collected germplasm of Amaranth spp including nine released varieties. These were evaluated during kharif and rabi of 2015 - 16 in RBD with two replications at farm of University of Horticultural Sciences, Bagalkot, Karnataka. In each replication, each entry was grown in two rows at $30 \mathrm{~cm}$ apart with row length of 5 $\mathrm{m}$, and plant-to-plant distance was $15 \mathrm{~cm}$. A basal dose of $50 \mathrm{~kg} \mathrm{ha}^{-1}$ each of $\mathrm{P}_{2} \mathrm{O}_{5}$ and $\mathrm{K}_{2} \mathrm{O}$ along with nitrogen $100 \mathrm{~kg} \mathrm{ha}^{-1}$ was applied through single super phosphate, muriate of potash and urea respectively. All recommended package and practices were followed to raise good crop. The crop was harvested at 40 DAS by clipping shoots from the $10 \mathrm{~cm}$ above the ground level. the Observations were recorded on ten important quantitative traits namely, plant height at 15 DAS $(\mathrm{cm})$, plant height at 30 DAS $(\mathrm{cm})$, stem diameter $(\mathrm{cm})$, leaf length $(\mathrm{cm})$, leaf breadth $(\mathrm{cm})$, petiole length $(\mathrm{cm})$, leaf to stem ratio, leaf dry matter content $(\%)$, stem dry matter content (\%) and total dry matter content $(\%)$.The observations for all the traits were recorded on five randomly selected plants in each of the accession per replication and the data were statistically analyzed. The GCV and PCV was computed according to the Burton method (Burton and Devane, 1953) whereas, Heritability and genetic advance were calculated according to the method suggested by Johnson et al., (1955).

\section{Results and Discussion}

The analysis of variance revealed significant differences between the strains in all the ten characters, which were validated by further statistical and genetic analyses (Table 1).

Variability plays a vital role for the selection of superior genotypes in crop improvement program. Pronounced variation in the breeding materials is prerequisite for development of varieties for existing demand. Selection of genotypes on the basis of their phenotypic variation (mean and range) is impractical for a breeder. Actual genetic variation may be masked by its environmental influence. Therefore, partitioning the phenotypic variation into genotypic and environmental effects is essential for selection of suitable genotypes. The genotypic variance was highest for plant height at 30 DAS $(\mathrm{cm})$ during kharif and rabi seasons (91.51 and 104.99 respectively) indicating greater scope of selection (Table 2). The values of phenotypic coefficient of variation (PCV) were higher than those of genotypic coefficient of variation 
(GCV) for all the characters during both kharif and rabi seasons, though the differences were small for all the traits except petiole length $(\mathrm{cm})$ and leaf breadth $(\mathrm{cm})$, indicated that the variability was predominately due to genotypic for all traits except petiole length and leaf breadth, i.e. little environmental influences. Similar results were obtained by Pan et al., 2008, Shukla et al., 2006, and Revanappa and Madalageri, 1998 in amaranth and Rastogi et al., (1995) in Brassica.

The GCV range from $11.53 \%$ to $42.92 \%$ during kharif season and range was from $10.25 \%$ to $42.12 \%$ during rabi season, while PCV ranged from $13.93 \%$ to $46.18 \%$ during kharif season and from $13.56 \%$ to $46.47 \%$ during rabi season.

High GCV and PCV values were found for plant height at 15 DAS (GCV 42.92 and 42.12; PCV 46.18 and 46.47), plant height at 30 DAS (GCV 23.30 and 24.83; PCV 24.77 and 28.13), stem diameter (GCV 26.23 and 21.76; PCV 30.98 and 24.90), leaf length (GCV 28.02 and 27.83; PCV 30.19 and 29.45), leaf breadth (GCV 27.66 and 25.70; PCV 34.44 and 28.21), leaf to stem ratio (GCV 36.35 and 32.54; PCV 37.41 and 34.01) and stem dry matter content (GCV 30.21 and 27.59; PCV 31.69 and 29.43) during both kharif and rabi seasons respectively, indicating the potential of simple selection for the improvement of these characters. These results are in accordance with Pan et al., (2008), who observed high GCV and PCV for leaf to stem ratio, girth of stem and length of leaf. Similar results also reported by Revanappa and Madalgeri (1998) for plant height and dry weight per plant. Chattopadhyay et al., (2013) for plant height, stem diameter and leaf to stem ratio.

Traits with high broad sense heritability estimates suggest that they have high genetic potential; the effect of the environment in determining them is low. The values of heritability estimates were high for all the character except petiole length $(\mathrm{cm})$ and leaf dry matter content $(\%)$ during both kharif and rabi seasons. The range was from $38.50 \%$ to 94.40 for petiole length $(\mathrm{cm})$ and leaf to stem ratio respectively during kharif season whereas for rabi season heritability range was from 34.50 to 91.50 for petiole length and leaf to stem ratio respectively. High heritability values in vegetable amaranths have also been reported by Revanappa and Madalageri (1998), Shukla et al., (2006) and Anuja (2012.

High heritability alone is not enough to make sufficient improvement through selection generally in advance generations unless accompanied by substantial amount of genetic advance (Bhargava et al., 2004). High heritability and moderate to high genetic advance over mean was recorded for plant height at $15 \mathrm{DAS}()$, plant height at $30 \mathrm{DAS}$, stem diameter, leaf length, leaf breadth, leaf to stem ratio and stem dry matter content at both kharif and rabi seasons, indicating additive gene action and the selection based on these parameters would be more reliable.

Previous workers Pan et al., (2008), Shukla et al., (2006), Anuja (2012) and Chattopadhaya et al., (2013) also supported our findings for plant height, leaf to stem ratio, stem diameter. High heritability and low genetic advance over mean were reported for total dry matter content during both kharif and rabi seasons, indicating advancement of non additive gene action and the high heritability is being exhibited due to favorable influence of the environment rather than genotype.

This result corroborates earlier observations of Anuja 2012 for total dry matter content. Low heritability and low genetic advance over mean for petiole length indicated that selection based on this character will be less effective (Johnson et al., 1955). 
Table.1 Analysis of variance (mean squares) for different growth and quality parameters in amaranth during rabi season

\begin{tabular}{|c|c|c|c|c|c|c|c|}
\hline \multirow[t]{2}{*}{$\begin{array}{l}\text { Sl. } \\
\text { No }\end{array}$} & $\begin{array}{c}\text { Source of } \\
\text { variation/characters }\end{array}$ & Season & Replication & $\begin{array}{c}\text { Treatment } \\
\text { (Genotypes) }\end{array}$ & Error & $\begin{array}{l}\text { C.D. } \\
(1 \%)\end{array}$ & $\begin{array}{l}\text { C.D. } \\
(5 \%)\end{array}$ \\
\hline & Degrees of freedom & & 1 & 43 & 43 & & \\
\hline A. & \multicolumn{7}{|l|}{ Growth parameters } \\
\hline \multirow[t]{2}{*}{1.} & \multirow[t]{2}{*}{ Plant height at 15 DAS $(\mathrm{cm})$} & Kharif & 0.00016 & 55.02 & 4.01 & 5.40 & 4.04 \\
\hline & & $R a b i$ & 0.026 & 55.53 & 5.44 & 6.28 & 4.70 \\
\hline \multirow[t]{2}{*}{2.} & \multirow[t]{2}{*}{ Plant height at 30 DAS $(\mathrm{cm})$} & Kharif & 0.89 & 194.90 & 11.89 & 9.29 & 6.9 \\
\hline & & $R a b i$ & 0.122 & 239.692 & 29.71 & 14.69 & 10.99 \\
\hline \multirow[t]{2}{*}{3.} & \multirow{2}{*}{ Stem diameter $(\mathrm{cm})$} & Kharif & 0.017 & 0.10 & 0.016 & 0.34 & 0.26 \\
\hline & & $R a b i$ & 0.00016 & 0.079 & 0.0106 & 0.27 & 0.20 \\
\hline \multirow[t]{2}{*}{4.} & \multirow[t]{2}{*}{ Leaf length $(\mathrm{cm})$} & Kharif & 1.04 & 16.70 & 1.24 & 3.00 & 2.25 \\
\hline & & $R a b i$ & 1.243 & 15.26 & 0.864 & 2.50 & 1.87 \\
\hline \multirow[t]{2}{*}{5.} & \multirow[t]{2}{*}{ Leaf breadth $(\mathrm{cm})$} & Kharif & 0.20 & 7.43 & 1.60 & 3.41 & 2.55 \\
\hline & & $R a b i$ & 0.62 & 5.92 & 0.54 & 1.99 & 1.49 \\
\hline \multirow[t]{2}{*}{6.} & \multirow[t]{2}{*}{ Petiole length (cm) } & Kharif & 0.36 & 2.75 & 1.22 & 2.98 & 2.23 \\
\hline & & $R a b i$ & 1.36 & 1.94 & 0.945 & 2.62 & 1.96 \\
\hline \multirow[t]{2}{*}{7.} & \multirow[t]{2}{*}{ Leaf to stem ratio } & Kharif & 0.038 & 0.53 & 0.015 & 0.33 & 0.24 \\
\hline & & Rabi & 0.036 & 0.41 & 0.018 & 0.36 & 0.27 \\
\hline \multirow[t]{2}{*}{8.} & \multirow[t]{2}{*}{ Leaf dry matter content $(\%)$} & Kharif & 1.25 & 5.39 & 1.00 & 2.70 & 2.02 \\
\hline & & Rabi & 1.053 & 4.630 & 1.26 & 3.03 & 2.26 \\
\hline \multirow[t]{2}{*}{9.} & \multirow[t]{2}{*}{ Stem dry matter content ( $\%)$} & Kharif & 2.82 & 12.82 & 0.61 & 2.10 & 1.57 \\
\hline & & $R a b i$ & 0.281 & 10.58 & 0.681 & 2.22 & 1.66 \\
\hline \multirow[t]{2}{*}{10.} & \multirow[t]{2}{*}{ Total dry matter content (\%) } & Kharif & 7.85 & 22.04 & 2.49 & 4.26 & 3.18 \\
\hline & & Rabi & 0.24 & 19.89 & 3.086 & 4.73 & 3.54 \\
\hline
\end{tabular}


Table.2 Estimates of mean, range, components of variance, heritability and genetic advance for plant growth parameters in amaranth genotypes during kharif and rabi seasons

\begin{tabular}{|c|c|c|c|c|c|c|c|c|c|c|c|}
\hline $\begin{array}{l}\text { Sl. } \\
\text { No. }\end{array}$ & Character & Season & $\begin{array}{l}\text { Mean } \\
\pm \text { S.Em }\end{array}$ & Range & GV & PV & $\begin{array}{c}\text { GCV } \\
(\%)\end{array}$ & $\begin{array}{l}\text { PCV } \\
(\%)\end{array}$ & $\mathbf{h}^{2}$ & GA & $\begin{array}{c}\text { GAM } \\
(\%)\end{array}$ \\
\hline \multirow[t]{2}{*}{1} & \multirow{2}{*}{$\begin{array}{l}\text { Plant height at } 15 \text { DAS } \\
(\mathrm{cm})\end{array}$} & Kharif & $11.77 \pm 1.40$ & $4.80-26.32$ & 25.51 & 29.52 & 42.92 & 46.18 & 86.40 & 9.67 & 82.19 \\
\hline & & Rabi & $11.88 \pm 1.65$ & $4.34-25.28$ & 25.05 & 30.49 & 42.12 & 46.47 & 82.10 & 9.34 & 78.64 \\
\hline 2 & $\begin{array}{l}\text { Plant height at } 30 \text { DAS } \\
(\mathrm{cm})\end{array}$ & $R a b i$ & $41.26 \pm 3.85$ & $26.67-69.34$ & 104.99 & 134.71 & 24 & 28.13 & 77.90 & 18.63 & 45.16 \\
\hline \multirow[t]{2}{*}{3} & \multirow[t]{2}{*}{ Stem diameter $(\mathrm{cm})$} & Kharif & $0.79 \pm 0.09$ & $0.41-1.27$ & 0.04 & 0.06 & 26.23 & 30.98 & 71.70 & 0.36 & 45.77 \\
\hline & & $R a b i$ & $0.85 \pm 0.07$ & $0.50-1.25$ & 0.03 & 0.05 & 21.76 & 24.90 & 76.40 & 0.33 & 39.18 \\
\hline 4 & Leaf length $(\mathrm{cm})$ & $R a b i$ & $9.64 \pm 0.65$ & $4.74-15.42$ & 7.20 & 8.06 & 27.83 & 29.45 & 89.30 & 5.22 & 54.16 \\
\hline \multirow[t]{2}{*}{5} & \multirow[t]{2}{*}{ Leaf breadth $(\mathrm{cm})$} & Kharif & $6.17 \pm 0.88$ & $3.22-11.47$ & 2.92 & 4.52 & 27.66 & 34.44 & 64.50 & 2.83 & 45.76 \\
\hline & & $R a b i$ & $6.38 \pm 0.52$ & $4.00-10.71$ & 2.69 & 3.24 & 25.70 & 28.21 & 83.00 & 3.08 & 48.25 \\
\hline \multirow[t]{2}{*}{6} & \multirow[t]{2}{*}{ Petiole length $(\mathrm{cm})$} & Kharif & $4.96 \pm 0.77$ & $3.26-8.65$ & & 1. & & 28.45 & 38.50 & 1.12 & 22.56 \\
\hline & & $R a b i$ & $5.08 \pm 0.68$ & $3.04-7.39$ & 0.50 & 1.44 & 13.90 & 23.65 & 34.50 & 0.86 & 16.82 \\
\hline 7 & Leaf to stem ratio & Kharif & $1.40 \pm 0.08$ & $0.65-2.45$ & 0.26 & 0.28 & & 37.41 & 94.40 & 1.02 & 72.78 \\
\hline \multirow[t]{2}{*}{9} & \multirow{2}{*}{$\begin{array}{l}\text { Stem dry matter content } \\
(\%)\end{array}$} & Kharif & $8.18 \pm 0.54$ & $3.60-13.88$ & 6.11 & 6.72 & 30.21 & 31.69 & 90.90 & 4.85 & 59.34 \\
\hline & & $R a b i$ & $8.06 \pm 0.58$ & $4.02-13.96$ & 4.95 & 5.63 & 27.59 & 29.43 & 87.90 & 4.30 & 53.29 \\
\hline \multirow[t]{2}{*}{10} & \multirow{2}{*}{$\begin{array}{l}\text { Total dry matter content } \\
(\%)\end{array}$} & Kharif & $21.02 \pm 1.10$ & $15.17-30.02$ & 9.77 & 12.27 & 14.87 & 16.66 & 79.60 & 5.75 & 27.33 \\
\hline & & $R a b i$ & $20.72 \pm 0.58$ & $14.53-28.87$ & 8.40 & 11.49 & 13.99 & 16.36 & 73.10 & 5.11 & 24.65 \\
\hline
\end{tabular}

$\begin{array}{lll}\text { GV } & - & \text { Genotypic variance } \\ \text { GCV } & - & \text { Genotypic coefficient of variance } \\ \text { PCV } & - & \text { Phenotypic coefficient of variance }\end{array}$




\section{References}

Anuja, S. 2012. Correlation and path coefficient analysis in amaranthus. Crop Res., 43 (1): 106-111.

Bhargava, A., Shukla, S., Chatterjee, A. and Singh, S.P. 2004. Selection response in vegetable amaranth (A. tricolor) for different foliage cuttings. Journal of Applied Horticulture, 6: 43-44.

Burton, G. W. and Devane, R. W. 1953. Estimating heritability in tall foscue (Festuca arubdinaces) from replicated clonal material. Agron. J., 45:478-481.

Chattopadhyay, A., Das, S., Rana, N.P., Seth, T. and Dutta, S. 2013. Estimation of genetic parameters relationships and genetic divergence of vegetable amaranths. Int. J. Plt. Bre., 7(2):111115.

Johnson, H. W., Robinson, H. F. and Comstock, R. S. 1955. Estimation of genetic and environmental variability in soyabean. Agron. J., 41: 314-318.

Joshi, B. D. and. Rana, R. S. 1995. Genetic divergence in grain amaranth (Amaranthus hypochondriacus). Indian J. of Agri. Sci., 65 (8): 605 607.

Katiyar R.S., Shukla S. and Rai S. 2000. Varietal performance of grain amaranth (A. hypochondriacus) on sodic soil. Proceedings of the National Academy of Sci., 70(b) II: 185-187.

Pan, R.S., Singh, A.K., Kumar, S. and Mathura, R. 2008. Genetic variation and character association in vegetable amaranth (Amaranthus tricolor 1.). Veg. Sci., 35(1): 81-83.
Prakash, D., and Pal, M. 1991. Nutritional and anti nutritional composition of vegetable and grain amaranth leaves. J. Sci. Food Agric., 57: 573-583.

Rastogi, K.B., Korla, B.N., Joshi, A.K., Thakur, M.C. 1995. Variability studies in Chinese cabbage (Brassica chinensis L.). Advances in Horticulture and Forestry, 4: 101107.

Revanappa, R. and Madalageri, B.B. 1998. Genetic variability studies regarding quantitative traits in amaranthus. Karnataka J. Agric. Sci., 11:139-142.

Shukla, S. and Singh, S.P. 2000. Studies on genetic parameters in vegetable amaranth. J. Gen. Breed., 54: 133135.

Shukla, S. and Singh, S.P. 2002. Genetic divergence in amaranth (A. hypochondriacus L.). Indian J. Gen Plt Breed., 64: 336-337.

Shukla, S., Pandey, V., Pachauri, G., Dixit, B.S., Ba-nerjii, R. and Singh, S.P. 2003. Nutritional contents of different foliage cuttings of vegetable amaranth. Plt Foods Human Nutri., 58: 1-8.

Shukla, S., Bhargava, A., Chatterjee, A., Srivastava, A. and Singh, S. P. 2006(a). Genotypic variability in vegetable amaranth (A. tricolor) for foliage yield and its contributing traits over successive cuttings and years. Euphytica. 151:103-110.

SINGH B.P., WHITEHEAD W.F., 1996. Management methods for producing vegetable amaranth. In: JANICK J. (ed.), Progress in New Crops. Arlington, VA, ASHS Press: 511-515.

\section{How to cite this article:}

Sheela N. Malaghan, S. Revanappa, Mansur, D. Satish and Ajjappalavar, P.S. 2018. Estimates of Genetic Variability for Growth Parameters in Amaranth (Amaranthus L.) Species. Int.J.Curr.Microbiol.App.Sci. 7(07): 1495-1500. doi: https://doi.org/10.20546/ijcmas.2018.707.176 